\title{
The Evaluation of Innovation Capacity of China and Its Influencing Factors
}

\author{
Khalid Usman ${ }^{1}$, Zhiying Liu ${ }^{1}$, Muhammad Naeem Anjum ${ }^{1} \&$ Sheng Bi ${ }^{1}$ \\ ${ }^{1}$ School of Management, University of Science \& Technology, Hefei, China \\ Correspondence: Zhiying Liu, School of Management, University of Science \& Technology, Hefei, China. Tel: \\ 86-158-0560-9709. E-mail: liuzhiyustc@163.com
}

Received: November 27, 2014 Accepted: February 10, 2015 Online Published: May 16, 2015

doi:10.5539/ass.v11n13p180 URL: http://dx.doi.org/10.5539/ass.v11n13p180

\begin{abstract}
This study aims to explore the factors affecting the national innovation capacity (NIC) of China. NIC is the capability of a nation to manufacture \& commercialize the stream of innovation technology over the "long term". The NIC of a country depicts not only industrial competitiveness of a country via a direct impact on the global market share of high tech products, but also determines its future potential for economic development. National innovation capacity depends upon the strength of national common innovation infrastructure, the industrial cluster innovation environment $\&$ therefore the strength of association among these two. Since reform and opening up of China, China innovation capability has made tremendous achievements, but the quality of the main innovation output is yet needed to be improved. The factors affecting the China's national innovation capacity include great human resource advantage of China, science \& technology infrastructure and a high capacity to absorb international technology spillovers. But the industry cluster innovation environment, still not provide enough support to knowledge-intensive services.
\end{abstract}

Keywords: national innovation capacity, innovation, endogenous growth theory, industry cluster, NIS

\section{Introduction}

In 1912 an Austrian-American economist (Schumpeter, 1912), introduced the idea of "Innovation" in his book "Theory of Economic Development" for the first time. He defined innovation as relocation of production function and a combination of new production function with the purpose of obtaining the profits. Afterward, Solow proposed two prerequisites of technological innovation, which are the sources of new ideas and the development of the subsequent stages of implementation in his paper "the innovation in capital process: review of Schumpeter's theory". "The process of technology innovation: the launching of new scientific industry (Paton \& McLaughlin, 2008), was the first article published in American economic view relevant to the innovation in 1950. (Enos, 1962), pointed out in his article "The invention and innovation in oil-processing industry" that the technological innovation is the combination of several functions including (1) invention selection, (2) capital accumulation, (3) organization establishment, (4) plan formulation, (5) worker recruitment (6) and market exploration. (Freeman \& Soete, 2009), defined technological innovation in his article "Research of success and failure in industrial innovation" as the entire process of technology, ability and commercialization that ends up in the introduction of latest products and therefore the commercial application of latest skills and technology within the market. According to (Mansfield, 1996), technological innovation is a multi-step process of introducing a new product and process, which include technology, design, production, finance, management and marketing, (Ross, 2001) while on the other hand, Seven Muller defined innovation as the integrated capacity of new product invention, production, technology improvement, reservance and organization.

The concept of innovation capacity was first time invoked by (Suarez-Villa, 1990). He stated that "In economic activity, innovation capability is that the measuring of the dynamics of invention". So, we have tendency to define NIC because the capacity of a nation to manufacture \& commercialize the stream of innovation technology over the "long term". Though the IC (innovation capacity) is connected with the level of development of technology, but there are essential differences between them. The capability of innovation emphasizes the effect of innovation technology rather than the evaluation of the degree of technology and hence is different from the industrial competitiveness and productivity; economy, good infrastructure and other factors unrelated to the industrialization of new technology. (Hall, 2007) defined that the innovation capacity may be a 
stock of positive capability that improves the state's economic output. Innovation capacity goes on the far side ancient measures of capital, labor and land, reflects the particular state of affairs to inspire service-based economies and modern knowledge and "new economy". It's a key driver of economic growth \& development, particularly within the "new economy" (Weber, 2005).

American Economist (Poter, 1990) introduced the Cluster-based theory of national industrial competitive advantage; (Romer, 1990), is more inclined towards the ideas-driven endogenous growth theory and the national innovation system(NIS) theory based on the NIC represent by the (Nelson, 1993). He emphasizes the role in the context of the evolution of national policy, education and institution environment for innovation. On the other hand (Freeman, 1987), proposed analytical framework of national innovation capabilities including the following three aspects, (1) ideas driven growth theory, (2) Microeconomic models of countrywide competitive advantage and business cluster and (3) Research on NIS. In the development of economic globalization and information technology, the rising of international trade, direct investment, and knowledge diffusion has been accelerating; a global technology spillover on the innovation ability of state, especially innovation has an important influence on the late-comer countries.

Among the countries crossing the significant level of innovation capacity, the gap between most innovative and their nearby competitors are diminishing. Although the world's most advanced innovative countries are still spending a lot on their innovation capacity, but the second member of group (middle tier) have invested on a huge rate and as a result, some of the countries from this class has excel greatly in the innovation capacity leaving behind those who are not investing accordingly to improve their national innovation system (Dosi, 1988; Freeman, 1987; Lundvall, 1992; Nelson, 1993).

The framework of (Furman, Porter, \& Stern, 2002), emphasis the country's infrastructure, commerce condition and the role of Govt policies. (Furman \& Hayes, 2004), modify this framework to clarify the variations and changes in selected 23 developed and newly industrialized countries between 1978 and 1999 that shown in Table 1. Considering the regression analysis of a good work between predictors of NIC and efficiently significant innovations, these countries are divided into four categories in (1) top innovator countries (2) middle tier; (3) 3rd tier and (4) rising innovator countries.

Table 1. Categorization of modernize nations

\begin{tabular}{llll}
\hline Top Innovator & Middle Tier & Third Tier & Rising Innovator \\
\hline USA & France & New Zealand & Finland \\
Japan & Norway & Spain & South Korea \\
Sweden & United Kingdom & Mexico & Ireland \\
Germany & Canada & Hungary & Denmark \\
Switzerland & Belgium & Italy & Iceland \\
& Netherlands & & \\
& Austria & & \\
& Australia & & \\
\hline
\end{tabular}

Sources: - Furman, R Hayes/Research Policy 33(2004).

Learning and imitation strategies of under developed countries are important to develop and enhance a country's innovative capacity at a rapid pace (Amsden, 1989; Furman \& Hayes, 2004; Hu, Jefferson, \& Qian, 2005; Kim \& Nelson, 2000; Narula, 2002). But according to (Bloomstorm \& Kokko, 1998; Buckley, Clegg, \& Wang, 2002; Coe \& Helpman, 1995; Grossman \& Helpman, 1991; Keller \& Yeaple, 2003; Liu \& Buck, 2007; Liu \& Wang, 2003; Sinani \& Meyer, 2004; Xu, 2000), above mentioned analytical framework for international technology has not taken into consideration the effects of integrated learning specially the oblique transfer of technological data through totally different activities and wide variety of spillovers channels like FDI and trade, which may influence the innovation performance of an endogenous firm. Furthermore, the cooperation between the innovations of local organizations and global technology spillovers sources has not yet been discovered in high tech sectors of emergent countries (Liu \& Buck, 2007). In innovation development, FDI was found to be an important factor, whichever positive (Chuang \& Hsu, 2004; Liu \& Wang, 2003) or negative (Hu \& Jefferson, 2002; Huang, 2004; Liu \& Wang, 2003). FDI may additionally bring advancement in knowledge, advancement in management talent, financial capital, human capital and new innovation concepts (Branstetter, 2006; Hu \& 
Jefferson, 2002; Liu \& Zou, 2008; Madariaga \& Poncet, 2007; Tuan \& Ng, 2009). According to (Anwar \& Nguyen, 2011), absorptive capacity is usually mentioned as a significant factor to confine spillover from FDI. It's bring into being that absorptive capacity affects the impact of information acquisition on innovation capacity at the company level in addition as national level. (Anwar \& Nguyen, 2011; Fu \& Gong, 2011; Liao, Wu, Hu, \& Tsui, 2009), It's acknowledges that R\&D efforts improve organization absorptive capacity (Liu, 2008). R\&D investment is that the ordinarily used proxy of absorptive capacity (Cohen \& Levinthal, 1990; Kostopoulos, Papalexandris, Papachroni, \& Ioannou, 2011; Lai, Peng, \& Bao, 2006). According to the American Economist (Poter, 1990), point of view, there are usually three stages of economic development, investment driven, innovation driven and factor-driven. Based on the experience of international development, GDP per capita between US \$ 1000-3000, and economic development typically need the factor-driven or investment driven to innovation-driven changes. Since the reform and opening up, China's rapidly growing economy is attracting the investors and obtaining worldwide attention. According to World Bank data, the current China's GDP per capita is about US \$6091. On 9th February, 2006 the state council devised an idea to make stronger the scientific and technological (S\&T) progress of China in the upcoming 15 years. The publication of the roadmap was scheduled each inside and outside of People's Republic of China for various reasons. The publication marks not solitary China's first long term roadmap within the new century ,however in addition to the 1st plan China introduced since turning into a member of the WTO. Most vital feature of the current long-term roadmap, spanning from 2006 to 2020, is also summarized in three points. First, extend research \& development expenses as a contribution to GDP. Second, to make stronger native innovation capability by reducing the reliance on overseas technology and companies/industries \& the commerce sector will be the vital dynamic force of innovation process. The Subject of this plan is "The National Program 2006-2020 for the Development of Science and Technology in the Medium and Long Term". The Govt. of China summarized the plan's ultimate objectives for China to attain by 2020 :

1) Build up technology associated with environment protection technology, water and energy resources.

2) Core technologies in IT \& production technology.

3) Come up to the foremost advance countries in designed areas among bio-technology.

4) Boost the speed of improvement in aviation technology and space technology also as oceanology.

5) make stronger every basic and strategic analysis.

This article focuses on why some countries are continuously ruling in technology; others still attempting to attain that technological catch-up, whereas remainder of countries are far behind due to inherent technical reasons, emphasizing the significance of the absorptive capacity of the international spillovers. This paper additionally makes an attempt to evaluate the China's country based innovation capability since 1999 to 2012 .

This research study is organized as follow: Section two the elements of NIC, section three describes the main features of the recent innovation in China and its impact on the evolution of input and output factors, following fourth section as conclusion and policy recommendations.

\section{National Innovation Capacity}

"National innovation capacity can be a nation's prospective as both a political entity \& economic. To investigate the creation of innovation sources of various countries beneath world's technology frontier, the framework introduced by (Furman et al., 2002). According to this framework, national innovation capability depends on overall technology sophistication of an economy and its labor forces, however conjointly replicate the investment policy selections by public and personal sectors that have an effect on the production of the country's Research \& Development companies/enterprises. (Dosi, 1988; Furman et al., 2002).This framework consists of three fundamentals (1) Common innovation infrastructure (2) industrial cluster-specific environment for innovation and (3) also the quality of association $\mathrm{b} / \mathrm{w}$ them. Strong common innovation infrastructure of a country in turn comprises resources commitments and its selections of policies, investment in learning and training, openness to world trade, preservation of intellectual's property, R\&D and overall casuistry in S\&T upon which new ideas are built and commercialized, as highlighted in figure 1. The common innovation infrastructures that support innovative activity, and overall technological levels has broad impact on country's economy (A), country's R\&D productivity further dependent upon its human and financial resources $\left(\mathrm{H}^{\mathrm{A}}\right)$, some other resources and polices that impact on the innovation activities $\left(\mathrm{X}^{\mathrm{INF}}\right)$, including intellectual property fortification, education and training investment, Research \& Development tax policies and openness to global trade. Common innovation infrastructure provides broad framework through an economy and enterprises/ firms in particular industrial clusters that develop \& commercialize the innovation. 


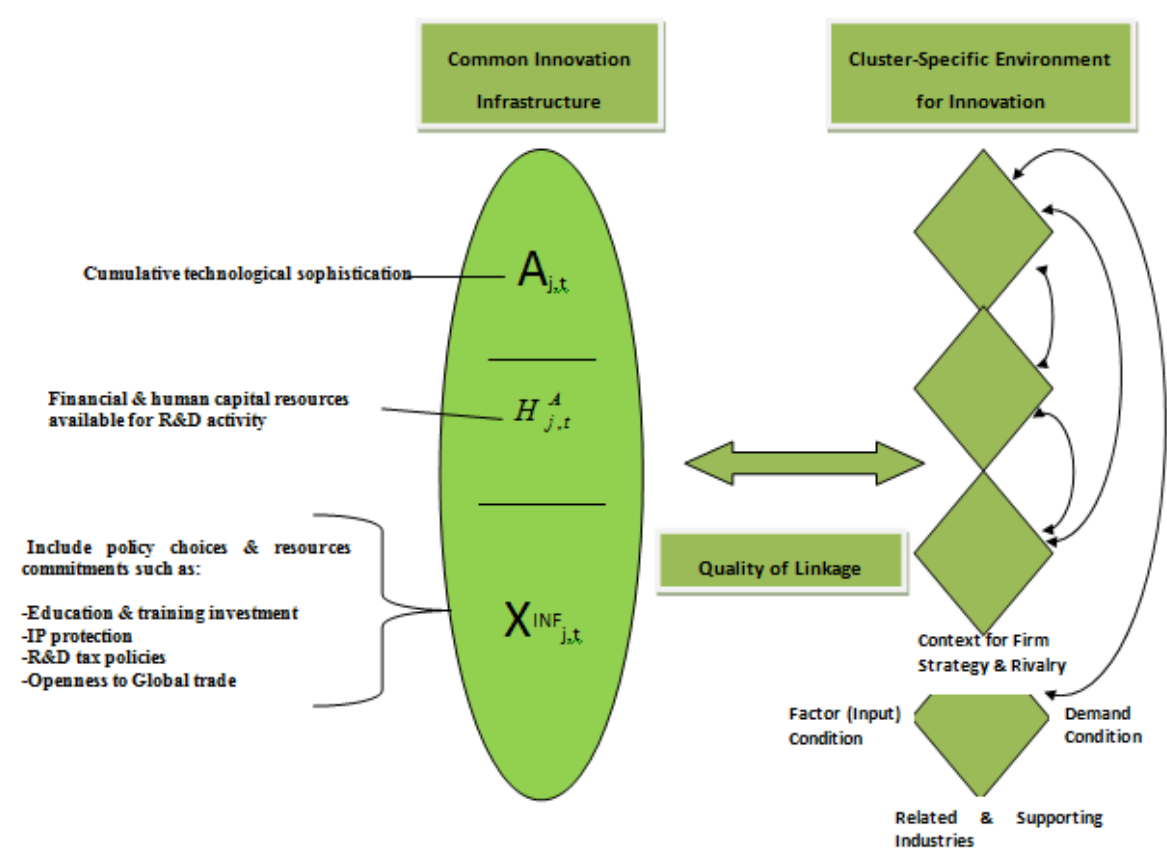

Figure 1. National innovation Capacity Framework (Porter Model. Re-printed. Furman, Porter \& Stern, 2002)

However, the relation between common innovation and cluster innovation environment are so important because cluster innovation environment therefore necessary as a result of the strength of the common innovation infrastructure. The Endogenous growth theory basis of the NIC framework, which is relatively new available technology (new-to-the-world technologies).

$$
A_{j, t}=\delta_{j, t}\left(X_{j, t}^{I N F}, Y_{j, t}^{C L U S}, Z_{j, t}^{L I N K}\right) H_{j, t}^{A \lambda} A_{j, t}^{\phi}
$$

In equation (1), $A_{j, t}$ represents new-to-the-global technologies from nation $\mathrm{j}$ in year $\mathrm{t}, H_{j, t}^{A}$ represents the financial research department and also the overall level of human resources; $X_{j, t}^{I N F}$ refers to the cross-cutting level of resources and policies choice forming the common innovation infrastructure; $Y_{j, t}^{C L U S}$ is a country specific industry cluster that supports environment for innovation; $Z_{j, t}^{L I N K}$ shows a robust linkage $\mathrm{b} / \mathrm{w}$ the common innovation infrastructure and national industrialized clusters...

Empirical model derived from the Eq. (1), ought to address three questions: the sources of statistical identification, particular design of the innovation output manufacture function as well as the sources of the econometric miscalculation. First, the parameters relationship with Eq. (1) using a group data of 17 OECD countries over 20 years. These estimation was depends upon the cross-section variation, time-series variation or each/together. Cross-sectional variation offer the straight inter-country comparison that may tell the worth of the particular determination of national innovation capacity and also the time-series variation focus to its personal sources of endogeneity, however time-series deviation offer approaching into how a nation's choices apparent themselves in term of experimental innovation output. Concerning the sources of error, the anticipated worth given by Eq. (1) arises from a particularity year/country, particular knowledge distress dissimilar to the essential determinants of NIC. (Furman et al., 2002) Eq. (1) has corrected accordingly in logarithm form as follows:

$$
I A_{j, t}=\delta_{Y E A R} Y E A R+\delta_{\text {country }} C_{j}+\delta_{I N F} L X_{j, t}^{I N F}+\delta_{C L U S} L Y_{j, t}^{C L U S}+\delta_{L I N K} L Z_{j, t}^{L I N K}+\lambda L H_{j, t}^{A}+\phi L A_{j, t}+\varepsilon_{j, t}
$$


In Eq. (2), L denoted the natural logarithm, the positive constant on parts of $\delta_{\mathrm{INF}}, \delta_{\mathrm{CLUS}}$ and $\delta_{\mathrm{LINK}}$ denote the output of Research \& Development investment, the cluster specific environment for innovation and the quality linkages respectively. $A_{j, t}$ refers to international patenting, (HA) is Research \& Development input and the Research \& Development efficiency distinction of various countries are measured as (A).

\section{The Evaluation of Innovation Capacity of China and Its Influencing Factors}

\subsection{Innovation Input Indicators}

In Table 2 indicating factors affecting China's national innovation capacity are innovations infrastructure, industrial cluster innovation environment, quality linkage and the absorptive capacity of the international spillovers from 1999 to 2012.

Table 2. Factor affecting China innovation capability (Input indicators)

\begin{tabular}{|c|c|c|c|c|c|c|c|c|c|c|c|c|c|c|c|}
\hline Factors & & 1999 & 2000 & 2001 & 2002 & 2003 & 2004 & 2005 & 2006 & 2007 & 2008 & 2009 & 2010 & 2011 & 2012 \\
\hline \multirow{2}{*}{$\begin{array}{l}\text { Innovation } \\
\text { Infrastructu } \\
\text { re }\end{array}$} & 1 & $\begin{array}{l}82.1 \\
7\end{array}$ & $\begin{array}{l}92.2 \\
1\end{array}$ & $\begin{array}{l}95.6 \\
5\end{array}$ & 103.5 & 109.5 & 115.2 & 136.4 & 150.2 & 173.6 & 196.5 & 229.1 & 255.4 & 288.3 & 324.7 \\
\hline & 2 & $\begin{array}{l}678 . \\
9\end{array}$ & $\begin{array}{l}895 . \\
7\end{array}$ & 1042 & $\begin{array}{l}1287 . \\
6\end{array}$ & $\begin{array}{l}1539 . \\
6\end{array}$ & $\begin{array}{l}1966 . \\
3\end{array}$ & $\begin{array}{l}2450 . \\
0\end{array}$ & $\begin{array}{l}3003 . \\
1\end{array}$ & $\begin{array}{l}3710 . \\
2\end{array}$ & $\begin{array}{l}4616 . \\
0\end{array}$ & $\begin{array}{l}5802 . \\
1\end{array}$ & 7062.6 & 8687.0 & $\begin{array}{l}10298 . \\
4\end{array}$ \\
\hline \multirow{2}{*}{$\begin{array}{l}\text { Industry } \\
\text { cluster } \\
\text { innovation } \\
\text { environmen } \\
\mathrm{t}\end{array}$} & 3 & 8.7 & 9.3 & 9.5 & 9.9 & 10.5 & 10.9 & 11.5 & 12.7 & 12.9 & 13.3 & 13.5 & 13.9 & $\mathrm{n} / \mathrm{a}$ & $\mathrm{n} / \mathrm{a}$ \\
\hline & 4 & 20.3 & 29.4 & 32.4 & 33.7 & 35.1 & 36.3 & 38.6 & 40.9 & 40.3 & 44.3 & 43.3 & 42.9 & 43.9 & $\mathrm{n} / \mathrm{a}$ \\
\hline \multirow{2}{*}{$\begin{array}{l}\text { Quality Of } \\
\text { Linkage }\end{array}$} & 5 & 2.55 & 2.58 & 2.79 & 2.90 & 2.84 & 2.79 & 2.78 & 2.92 & 3.09 & 3.30 & 3.15 & 3.65 & 3.85 & $\mathrm{n} / \mathrm{a}$ \\
\hline & 6 & 0.76 & 0.90 & 0.95 & 1.07 & 1.13 & 1.23 & 1.32 & 1.39 & 1.40 & 1.47 & 1.70 & 1.76 & $\mathrm{n} / \mathrm{a}$ & $\mathrm{n} / \mathrm{a}$ \\
\hline \multirow{4}{*}{ 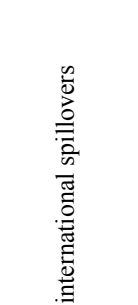 } & 7 & $\begin{array}{l}34.9 \\
4\end{array}$ & $\begin{array}{l}55.2 \\
4\end{array}$ & $\begin{array}{l}56.3 \\
2\end{array}$ & 57.07 & 59.37 & 64.02 & 65.52 & 66.28 & 67.44 & 69.82 & $\mathrm{n} / \mathrm{a}$ & $\mathrm{n} / \mathrm{a}$ & $\mathrm{n} / \mathrm{a}$ & $\mathrm{n} / \mathrm{a}$ \\
\hline & 8 & $\begin{array}{l}526 . \\
6\end{array}$ & $\begin{array}{l}593 . \\
6\end{array}$ & $\begin{array}{l}496 . \\
7\end{array}$ & $\begin{array}{l}550.1 \\
1\end{array}$ & $\begin{array}{l}561.4 \\
0\end{array}$ & 640.7 & 638.5 & $\begin{array}{l}670.7 \\
6\end{array}$ & $\begin{array}{l}783.3 \\
9\end{array}$ & $\begin{array}{l}952.5 \\
3\end{array}$ & $\begin{array}{l}918.0 \\
4\end{array}$ & $\begin{array}{l}1088.2 \\
1\end{array}$ & $\begin{array}{l}1176.9 \\
8\end{array}$ & $\begin{array}{l}1132.9 \\
4\end{array}$ \\
\hline & 9 & 6.7 & 5.1 & 4.6 & 4.6 & 4.4 & 4.4 & 4.2 & 3.6 & 3.4 & 2.9 & 1.8 & 1.6 & 1.5 & 1.1 \\
\hline & $\begin{array}{l}1 \\
0\end{array}$ & 3139 & 4021 & 4376 & 5430 & 7437 & 9969 & $\begin{array}{l}1225 \\
4\end{array}$ & $\begin{array}{l}1520 \\
4\end{array}$ & $\begin{array}{l}1869 \\
3\end{array}$ & $\begin{array}{l}2122 \\
9\end{array}$ & $\begin{array}{l}1854 \\
6\end{array}$ & 24585 & 29371 & $\mathrm{n} / \mathrm{a}$ \\
\hline 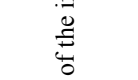 & $\begin{array}{l}1 \\
1\end{array}$ & 19.8 & 22.3 & 25.3 & 27.8 & 30.9 & 32.8 & 33.9 & 34.8 & 34.00 & 35.7 & 37.0 & 36.8 & 34.5 & $\mathrm{n} / \mathrm{a}$ \\
\hline \multirow{3}{*}{ 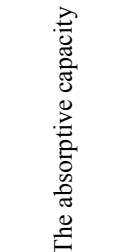 } & $\begin{array}{l}1 \\
2\end{array}$ & $\begin{array}{l}249 . \\
9\end{array}$ & $\begin{array}{l}353 . \\
4\end{array}$ & $\begin{array}{l}442 . \\
3\end{array}$ & 560.2 & 720.8 & 954.4 & $\begin{array}{l}1250 . \\
3\end{array}$ & $\begin{array}{l}1630 . \\
2\end{array}$ & $\begin{array}{l}2112 . \\
5\end{array}$ & $\begin{array}{l}2681 . \\
3\end{array}$ & $\begin{array}{l}3211 . \\
6\end{array}$ & 4015.4 & 5030.7 & $\mathrm{n} / \mathrm{a}$ \\
\hline & $\begin{array}{l}1 \\
3\end{array}$ & $\begin{array}{l}207 . \\
5\end{array}$ & $\begin{array}{l}245 . \\
4\end{array}$ & $\begin{array}{l}285 . \\
2\end{array}$ & 372.2 & 405.4 & 367.9 & 296.8 & 320.4 & 452.5 & 440.4 & 394.6 & 386.1 & $\mathrm{n} / \mathrm{a}$ & $\mathrm{n} / \mathrm{a}$ \\
\hline & $\begin{array}{l}1 \\
4\end{array}$ & 18.1 & 18.2 & 19.6 & 25.7 & 27.1 & 54 & 69.4 & 81.9 & 106.6 & 106.4 & 163.9 & 165.2 & $\mathrm{n} / \mathrm{a}$ & $\mathrm{n} / \mathrm{a}$ \\
\hline
\end{tabular}

Sources: CSY, China S\&T, China Statistical year book on High technology industry

Note: (1). Full-time Equivalent of Research \& Development personnel (1-million man-year); (2) Expenditure on Research \& Development (100-million RMB); (3) Percentage of value added of high-tech; (4) Knowledge-intensive service industry GDP \%; (5) Education expenditure on GDP \%; (6) Government technology investment to GDP \%; (7) Industrial R\&D of total R\&D expenditure \%; (8) FDI absolute value (100 U.S \$ billion) Total amount of Foreign investment; (9) FDI in fixed assets in whole country (\%); (10) Manufactured good trade(US\$ billion); (11) Import and export high-tech products $\%$ of total manufactured goods; (12) R\&D Expenditure (100-million RMB); (13) Expenditure for Acquisition of Foreign Technology (100-million RMB); (14) Expenditure for Assimilation of Technology (100-million RMB).

First, for the innovation infrastructure, select the two indicators full-time equivalent of Research \& Development, personnel \& expenditure on Research \& Development, in Table 2 from 1999 to 2012. According to innovation infrastructure R\&D personnel of "full time" equivalent though some fluctuation but, overall has been rising steadily. All over the world the China is the most populous country and the technology \& human resources are distinctive advantages. During this period, the $R \& D$ expenditure index growth increased so quickly that shows 
that the China gives more importance to Research \& Development activities on behalf of innovation. In China, the Research \& Development department is becoming increasingly important to promote innovation and support economic growth, and is additionally attempting to concentrate on innovation-driven stage of development. Second, industry cluster innovation environment (with industry geographic concentration index) reflects the geographic concentration of Knowledge-spillover environment like manufacturing value added accounted for the proportion of high-tech industries \& knowledge-intensive services that effects the GDP of the country. As a leader of innovation, percentage of value added of high-tech industries rise from 1999-2012, however compare with international standard, the value added percentage of China high-tech industry is low. Knowledge-intensive industry is more and more vital for innovation, however the proportion of Knowledge-intensive industry is increasingly important for innovation, but the percentage of China knowledge-intensive industry is significantly lower. Third, the linkages of quality consist of education funding to GDP, Government Science \& Technology investment to GDP, reflects the Government commitment in innovation. Table 2 (1999-2012) education expenditure to GDP, Government science \& technology investment to GDP is comparatively constant that indicates that the government supporting role to spend on education \& technology is relatively stable, however as compared to international standards, the level of education and technology is significantly lower. Select the industrial Research \& Development versus total Research \& Development expenditure reflects the market in the process of innovation. From 1999-2012, funding to Research \& Development of total Research \& Development expenditure relatively has been improved. After the 2000, distinction is as due to the result of the reform of scientific research system. Fourth, absorptive capacity of international spillovers, with FDI, international trade \& technology imports related indicators reflect the international capacity to absorb technology spillover are listed in Table 2. FDI, since the reform and opening up, FDI perpetually increase in scale throughout the 1999 to 2012, after the 1999, FDI investment in fixed assets is showing rapid growth. China's national strength boost rapidly and the implementation of the strategy of expansion of domestic demand, the ratio has declined, however relatively stable. The structure of International trade and manufacturing good from 1999-2012 import trade continued to increase. Import and export high-tech products \% of total manufactured goods in 1999 was $19.8 \%$, however in 2011 this increase in $34.5 \%$.which reflects the technological learning export is in being cycle.

\subsection{Innovation Output Indicators}

The international paper (patent, upstream output index) and also the export of high technology products (downstream output index) analysis. Table 3 describes the change in indicators from 1999 to 2012.

We have tendency to select high-tech product exports (absolute amount) in downstream output indicator of China innovation capacity, and measure the high-tech exports relative to the total exports in proportion (relative amount) as seen in Table 3. The fast expansion of high-tech exports in absolute term reflects that China high-tech product is gradually increasing within the global market and also the high-tech exports in total exports proportion has been increasing steadily. This increase suggests the China's progress in high technology. Whereas investigating patents, we have got chosen the amount of patents (domestic and foreign inventions, utility model, and design patents) as indicators, as shown in Table 3 the output of china's innovation is described by the total growth rate of approved patents and proprietary invention additionally indicates the highest valued patents. Since the domestic patents produced by China are too high however a large percentage of those patents are substandard therefore expressing the very fact that the native innovation capacity of China is not strong. The utility model and design are mainly components of the patent, though the share has decreased, but its absolute advantage position additionally suggests that the overall quality of the Chinese patent is not high.

In the upstream innovation output indicators, we have selected the total number of SCI papers, and their annual average citations per paper are analyzed as apparent from Table 3. As the rapid growth of SCI papers reflects the country's capability and knowledge of their basic research, annual average citations per paper are much less than their average growth rate, further indicating that the average quality of SCI papers is not high at all. The data about published SCI papers is given in Table 3, whereas the data interval in years and the SCI papers growth rate is presented in Table 4 . 
Table 3. China innovation capability (Output indicators)

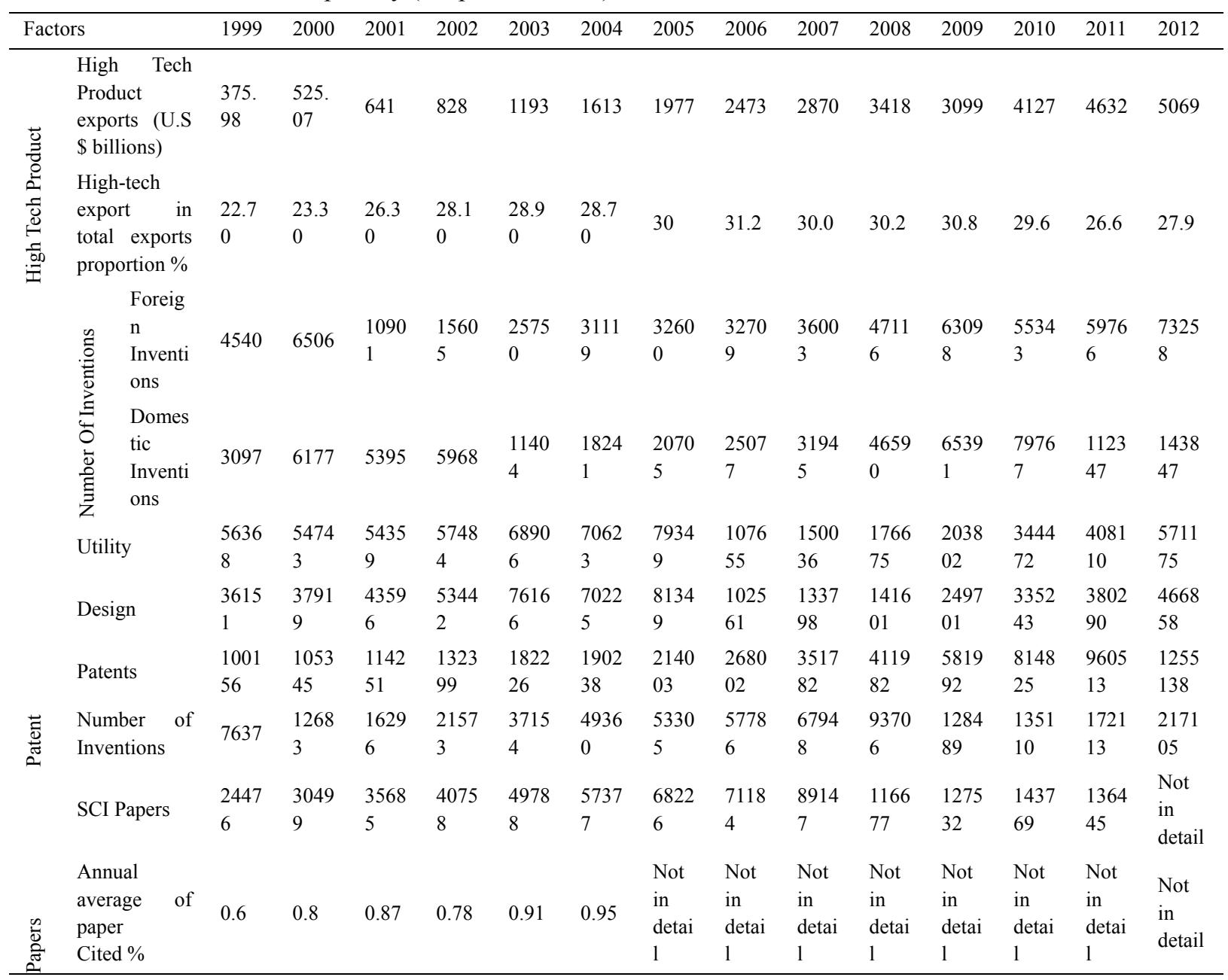

Sources: CSY, China S\&T statistical yearbook.

Table 4. China scientific papers in 5-year over lapping taken in SCI (Citation impact)

\begin{tabular}{|c|c|c|c|c|c|c|c|c|}
\hline Items & 1999-2003 & $2000-2004$ & 2001-2005 & 2002-2006 & 2003-2007 & 2004-2008 & 2005-2009 & 2006-2010 \\
\hline $\begin{array}{l}\text { SCI } \\
\text { Papers }\end{array}$ & 152946 & 175913 & 210099 & 249582 & 349560 & 414391 & 472766 & 548309 \\
\hline $\begin{array}{l}\text { Number } \\
\text { of Paper } \\
\text { Cited }\end{array}$ & 332297 & 412145 & 549879 & 692283 & 936676 & 1206096 & 1796896 & 2362146 \\
\hline Impact & 1.97 & 2.34 & 2.62 & 2.77 & 2.68 & 2.91 & 3.80 & 4.31 \\
\hline
\end{tabular}

Sources: CSY, China S\&T statistical yearbook

This Table 4 shows that the SCI is much high but the annual average citation per paper is much less than the growth rate of papers. In significantly, Chinese innovation output in the upper, middle and lower indicators such as patents, SCI papers, and high-tech products export, these three types of indicators are in the absolute number of rapid expansion, showing an exponential growth trend, which reflects that China's recent reforms have increased Chinese innovation capacity steadily. however in relation to China's internal structure, still there are some deficiencies, like invention patents proportion is much lower than the foreign invention patents, the SCI paper citation average is less than the growth of papers, indication that the overall quality of China's innovation capacity is not high and also the independent innovation capability is not strong. 


\section{Conclusion and Recommendations}

International competitiveness and also the role within the global economy depend upon the innovation capacity of a country. This study proposed (Furman, Porter, \& Stern, 2002; Furman \& Hayes, 2004) analytical framework for national innovation capacity to investigate the main factors of NIC, absorptive capacity of international spillovers, innovation infrastructure, industry cluster innovation environment and quality of linkages. On the basis of above mentioned framework, we chose to evaluate the standard indicators of China's reform and opening up in recent years. We are able to get major conclusion as below:

First, since 1999 innovation output indicators of China like patents, international papers (upstream output indicators) and high-tech exports (downstream output indicators) are progress enormously and even showed almost an exponential growth trend. However some innovation output indicators such as patents, domestic invention patents and international paper cited shows that the China innovation output quality is not high. As a whole since the start of reform and opening up, China innovation capability has made tremendous achievements, however the quality of the main innovation output is required to be improved. Second, investigate the determinants of national innovation capabilities in four areas; China has obvious advantage in term of innovation infrastructure, particularly obvious advantage in scientific and technology (HR) personnel. The overflow of China international technology is strong, the best thing about opening up since the FDI that enhance the international trade, technology transfer \& other international technologies spillovers channels. On the other hand, industrial cluster innovation environment of China remains not ideal, such as the function of knowledge intensive bushiness services (KIBS) in innovation is not noticeable. Additionally, the quality of linkage between the scientific research and industry sector is not enough, as countries in term of basic education, gives enough supporting role, industries because the main body of the pattern of innovation remain in formation. According to this analysis, we have a tendency to make following suggestions to extend the China national innovation capacity: First, the china has a great advantage within the availability of human resource; it is strongly recommended that $R \& D$ funding should be increased further to improve the innovation infrastructure. Second to improve the industry cluster innovation environment, focusing on strengthening the industrial agglomeration at the same time is essential to extend the role of high tech industry and knowledge intensive services in innovation. The third suggestion is that to improve the linkage of quality between science \& technology and industrial sectors. Moreover, the government ought to play a vital role to strengthen the training and education, basic research as well as other research programs etc. Fourth, pay a lot of attention to the role of market in innovation and obtain a lot of advantage of foreign and domestic scientific and technologies resource, speeding up the management innovation to provide strong support to technology innovation.

\section{References}

Amsden, A. (1989). Asia's Next Giant: South Korea and Late industrialize. Oxford University Press, New York.

Anwar, S., \& Nguyen, L. P. (2011). Foreign direct investment and trade: The case of Vietnam. Research in International Business and Finance, 25(1), 39-52. http://dx.doi.org/10.1016/j.ribaf.2010.05.004

Bloomstorm, M., Kokko, A. (1998). Multinational corporations and spillovers. Journal of Economic Surveys, 12(2), 1-31. http://dx.doi.org/10.1111/1467-6419.00056

Branstetter, L. (2006). Is foreign direct investment a channel of knowledge spillovers? Evidence from Japan's FDI in the United States. Journal of International Economics, 68(2), 325-344. http://dx.doi.org/10. 1016/j.jinteco.2005.06.006

Buckley, P., Clegg, J., \& Wang, C. (2002). The impact of inward foreign direct investment on the nature and intensity of Chinese manufacturing exports. Journal of International Business Studies, 33, 637-655. http://dx.doi.org/10.1057/palgrave.jibs.8491037

Chuang, Y. C., \& Hsu, P. F. (2004). FDI, trade, and spillover efficiency: Evidence from China's manufacturing sector. Applied Economics, 36(10), 1103-1115. http://dx.doi.org/10.1080/0003684042000246812

Coe, D., \& Helpman, E. (1995). International R \& D spillovers. European Economic Review, 39, 859-887. http://dx.doi.org/10.1016/0014-2921(94)00100-E

Cohen, W. M., \& Levinthal, D. A. (1990). Absorptive capacity: A new perspective on learning and innovation. Administrative Science Quarterly, 35(1), 128-152. http://dx.doi.org/10.2307/2393553

Dosi, G. (Ed.). (1988). Techinical Change and Economic Theory. Pinter. Publishers, London, UK.

Enos, J. (1962). Invention and innovation in the petroleum refining industry. The Rate and Direction of Inventive Activity: Economic, I, 299-322. 
Freeman, C. (1987). Technology Policy and Economic Performance: Lesson from Japan. Pinter, London, UK.

Freeman, C., \& Soete, L. (2009). Developing science, technology and innovation indicators: What we can learn from the past. Research Policy, 38(4), 583-589. http://dx.doi.org/10.1016/j.respol.2009.01.018

Fu, X., \& Gong, Y. (2011). Indigenous and Foreign Innovation Efforts and Drivers of Technological Upgrading: Evidence from China. World Development, 39(7), 1213-1225. http://dx.doi.org/10.1016/j.worlddev.2010. 05.010

Furman, J. L., \& Hayes, R. (2004). Catching up or standing still? National innovation productivity among followers countries. Research Policy, 33(9), 1329-1354. http://dx.doi.org/10.1016/j.respol.2004.09.006

Furman, J. L., Porter, M. E., \& Stern, S. (2002). The determinants of national innovative capacity. Research Policy, 31(2002), 899-933. http://dx.doi.org/10.1016/S0048-7333(01)00152-4

Grossman, G., \& Helpman, E. (1991). International and Growth in the Global Economy. Cambridge: MA, MIT Press.

Hall, J. L. (2007). Understanding state economic development policy in the new economy: A theoretical foundation and empirical examination of state innovation in the U.S. Public Administration Review, 4(67), 630-646. http://dx.doi.org/10.1111/j.1540-6210.2007.00749.x

Hu, A. G., \& Jefferson, G. H. (2002). FDI Impact and Spillover: Evidence from China's Electronic and Textile Industries. World Economy, 25(8), 1063-1076. http://dx.doi.org/10.1111/1467-9701.00481

Hu, A., Jefferson, G., \& Qian, J. (2005). R \& D and Technology Transfer : Firm-Level Evidence from Chinese Industry 1. Review of Economic and Statistics, (582). http://dx.doi.org/10.1162/003465305775098143

Huang, J. T. (2004). Spillovers from Taiwan, Hong Kong, and Macau Investment and from Other Foreign Investment in Chinese Industries. Contemporary Economic Policy, 22(1), 13-25. http://dx.doi.org/10.1093 /cep/byh002

Keller, W., \& Yeaple, S. (2003). Multinatioonal enterprises, international trade, and productivity growth: Firm level evidence from the United States. NBER Working Papers No, 9505.

Kim, L., \& Nelson, R. (2000). Technology, Learning and Innovation: Experiences from Newly Industrializing Economies. In Cambridge University Press, Cambridge.

Kostopoulos, K., Papalexandris, A., Papachroni, M., \& Ioannou, G. (2011). Absorptive capacity, innovation, and financial performance. Journal of Business Research, 64(12), 1335-1343. http://dx.doi.org/10.1016/j.jbusres. 2010.12.005

Lai, M., Peng, S., \& Bao, Q. (2006). Technology spillovers, absorptive capacity and economic growth. China Economic Review, 17(3), 300-320. http://dx.doi.org/10.1016/j.chieco.2006.04.005

Liao, S. H., Wu, C. C., Hu, D. C., \& Tsui, K. A. (2009). Relationships between knowledge acquisition, absorptive capacity and innovation capability: An empirical study on Taiwan's financial and manufacturing industries. Journal of Information Science, 36(1), 19-35. http://dx.doi.org/10.1177/0165551509340362

Liu, X., \& Buck, T. (2007). Innovation Performance and Channels for International Technology Spillover: Evidence from Chinese High-tech industries. Research Policy, 36(3), 355-366. http://dx.doi.org/10.1016/j. respol.2006.12.003

Liu, X., \& Wang, C. (2003). Does foreign direct investment facilitate technological progress? Evidence from Chinese industries. Research Policy, 32, 945-953. http://dx.doi.org/10.1016/S0048-7333(02)00094-X

Liu, X., \& Zou, H. (2008). The impact of Greenfield FDI and mergers and acquisitions on innovation in Chinese high-tech industries. Journal of World Business, 43(3), 352-364. http://dx.doi.org/10.1016/j.jwb.2007. 11.004

Liu, Z. (2008). Foreign direct investment and technology spillovers: Theory and evidence. Journal of Development Economics, 85(1-2), 176-193. http://dx.doi.org/10.1016/j.jdeveco.2006.07.001

Lundvall, B. A. (1992). National System of Innovation: Towards a Theory of Innovation and Interactive Learning. Pinter. London, UK.

Madariaga, N., \& Poncet, S. (2007). FDI in Chinese Cities: Spillovers and Impact on Growth. The World Economy, 30(5), 837-862. http://dx.doi.org/10.1111/j.1467-9701.2007.01025.x 
Mansfield, E. (1996). The Modern University: Contributor to Industrial Innovation and Recipient of Industrial R\&D Support. Research Policy, 25, 1047-1058. http://dx.doi.org/10.1016/S0048-7333(96)00893-1

Narula, R. (2002). The implication of growing cross-border interdependence for system of innovation. MERIT-Infonomics Research Memorandum Series No. 16.

Nelson, R. R. (1993). National Innovation System: A comparative analysis. New York: Oxford University Press.

Paton, R. A., \& McLaughlin, S. (2008). Services innovation. European Management Journal, 26(2), 77-83. http://dx.doi.org/10.1016/j.emj.2008.01.004

Poter, M. E. (1990). The Competitive Advantage of Nations. New York: Free Press.

Romer, P. M. (1990). Endogenous Technological Change. Journal of Political Economy, 98, S71-S102. http://dx.doi.org/10.1086/261725

Ross, T. J. (2001). Fuzzy Logic and Engineering Application (pp. 124-128). Digital Engineering Press.

Schumpeter, J. (1912). The Theory of Economic Development (10th ed.). New Brunswick, New Jersey: Transaction Publishers.

Sinani, E., \& Meyer, K. (2004). Spillovers of technology transfer from FDI: The case of Estonia. Journal of Comparative Economics, 32(3), 445-466. http://dx.doi.org/10.1016/j.jce.2004.03.002

Suarez-Villa, L. (1990). Invention, Inventive learning and innovative capacity. Behavioral Science, 35(4), 290-310. http://dx.doi.org/10.1002/bs.3830350404

Tuan, C., \& Ng, L. (2009). China's post-economic reform growth: The role of FDI and productivity progress. Journal of Asian Economics, 20(3), 280-293. http://dx.doi.org/10.1016/j.asieco.2009.02.010

Weber, B. L. et al. (2005). A critical review of rural poverty literature: Is there truly a rural effect? International Regional Science Review, 4(28), 381-414. http://dx.doi.org/10.1177/0160017605278996

$\mathrm{Xu}, \mathrm{B}$. (2000). Multinational enterprises, technology diffusion, and host country productivity growth. Journal of Development Economics, 62, 477-493. http://dx.doi.org/10.1016/S0304-3878(00)00093-6

\section{Copyrights}

Copyright for this article is retained by the author(s), with first publication rights granted to the journal.

This is an open-access article distributed under the terms and conditions of the Creative Commons Attribution license (http://creativecommons.org/licenses/by/3.0/). 